\title{
Parturient behaviour of Djallonké ewes and West African dwarf does
}

\author{
I. I. ABDUL-RAHMAN, E. K. AWOTWI, B. AWUMBILA \& K. OPPONG-ANANE \\ (I. I. A.-R., E. K. A. \& B. A.: Department of Animal Science, University of Ghana, P. O. Box LG 226, \\ Legon, Accra, Ghana; K. O.-A.: Animal Production Directorate, Ministry of Food and Agriculture, \\ P. O. Box AN 5779, Accra-North, Ghana)
}

\begin{abstract}
The parturient behaviour of 52 Djallonké ewes and 70 West African dwarf does was observed. The parameters recorded were the duration of parturition, posture during birth, presentation of the neonate at birth, and interventions during birth. The effects of parity, age and number of foetuses carried on the aforementioned parturient behavioural parameters were analysed using the chi-square procedure and a two-tailed t-test. The results of the study on Djallonké ewes showed that birth was completed in recumbent position by 73.1 per cent of the ewes while 98.1 per cent of them presented their lambs normally. None of the ewes required assistance during delivery. The duration of labour averaged $42 \mathrm{~min}$ while the time interval between the births of first and second-born twins averaged $3.8 \mathrm{~min}$. The age, parity and number of foetuses carried had no significant effect $(P>0.05)$ on the position in which birth was completed by ewes and presentation of lambs at birth. However, labour was longer in primiparous and young ewes than in multiparous and old ewes. Similarly, twin-bearing ewes were in labour longer than single-bearing ewes. The results of the study on goats showed that most $(82.9 \%)$ does studied completed birth in recumbent position while 94.3 per cent presented their foetuses normally. No assistance was needed by any of the does during delivery. On the average, labour lasted for $20.57 \mathrm{~min}$ while the time interval between the births of first and second-born twins lasted about $6 \mathrm{~min}$. Age and parity of the dam did not significantly affect $(P>0.05)$ the duration of labour and presentation of kids at birth; but significantly, most $(P<$ $0.05)$ primiparous and young does completed birth in recumbent position compared to multiparous and old does. The number of foetuses carried had no effect on all the parturient behavioural parameters studied.
\end{abstract}

\begin{abstract}
RÉSUMÉ
Abdul-Rahman, I. I., Awotwi, E. K., Awumbila, B. \& OppongANANE, K.: Comportment de parturiente des agnelles de Djallonké et des chèvres naines ouest-africaines. Les observations étaient faites du comportement de parturiente de cinquante-deux (52) agnelles de Djallonké et de soixantedix (70) chèvres naines ouest-africaines. Les paramètres enregistrés étaient la durée de parturition, la posture pendant l'accouchement, présentation du nouveau-né à la naissance et les interventions pendant les accouchements. Les effets de parité, d'âge et de nombre des fætus portés sur les paramètres behavioristes susdits de parturiente étaient analysés avec la procédure d'équerre en chi et d'essai T à deux queues. Les résultats de l'étude sur les agnelles de Djallonké révélaient que l'accouchement était terminé en une position allongée par $73.1 \%$ des agnelles alors que $98.1 \%$ d'elles présentaient leurs agneaux normalement. Aucunes des agnelles n'exigeaient d' aide pendant l'accouchement. La durée du travail était $42 \mathrm{~min}$ de moyenne alors que l'intervalle du temps entre les naissances du premier et du second des jumeaux nés était $3.8 \mathrm{~min}$. de moyenne. L'âge, la parité et le nombre de fætus portés n'avaient aucun effet considerable $(P>0.05)$ ni sur la posture à la naissance. Le travail était cependant plus long chez les primipares et les jeunes agnelles que chez les multipares et les agnelles âgées. De la même façon, les agnelles portant les jumeaux avaient une durée de travail plus longue que celles des agnelles portant un seul agneau. Les résultats de l'étude sur les chèvres montraient que la majorité $(82.9 \%)$ des chèvres étudiées terminaient l'accouchement en une position allongée alors que $94.3 \%$ présentaient leurs fætus normalement. Aucune aide n'était exigée par les chèvres pendant l'accouchement. En moyenne, 1 travail durait $20.57 \mathrm{~min}$ alors que l'intervalle du temps entre les naissances du premier et du second des jumeaux nés durait à peu près 6 min. L'âge et la parité de la mère n'a pas eu un effet considérable $(P>0.05)$ sur la durée de travail et la présentation des chevreaux à la naissance, mais une proportion considérablement plus grande $(P<0.05)$ de
\end{abstract}

Ghana Jnl agric. Sci. 40, 59-66 
primipares et de chevrettes terminaient l'accouchement en une position allongée que les multipares et les chèvres âgées. Le nombre de fætus portée, d'autre part, n'avait Original scientific paper. Received 04 Aug 04; revised pas aucun effet sur tous les paramètres behavioristes de 28 Nov 05. parturiente étudiés.

\section{Introduction}

Sheep and goats are reared in almost all villages in West Africa and are of great economic importance to the villagers (Oppong, 1965). Unlike cattle, they can be kept as backyard animals because of their small sizes. Their ability to graze close to the ground ensures that they can use pasture more efficiently than cattle. Their shorter gestation period and tendency to produce twins and triplets make them more prolific than cattle. Sheep and goats produce useful products other than food, including wool, hair, hide, pelt, inedible tallow and greases and fatty acids (Robert \& Ralph, 1988). Other advantages that sheep and goats have over other livestock are their ability to survive and produce high quality meat even under marginal lands (FAO, 1986).

Parturient behaviour is characterised by a series of connected episodes which have been well documented in relatively few species. The reasons for this are several. According to Fraser (1968), parturition is relatively brief and rare compared to many other activities. Observations can only be recorded on animals individually and records can, therefore, only be built up slowly. Many free-living species choose remote or concealed places for the birth site, and housed animals avoid the hours of supervision for their parturitions. More births occur in domesticated ungulates during the hours of darkness than in the remainder of the day. For instance, over 80 per cent of mares foal at night and more cows calve at night than in the day (Fraser, 1968). In sheep, it has been found that although they seem to lamb throughout the 24-h period, a disproportionate number of ewes lamb in the early hours of darkness (Fraser, 1968).

Despite its importance to reproductive success, the parturient behaviour of female ungulates, especially tropical breeds of sheep and goats, has received less research attention compared to behaviour during established lactation.

The objective of this study, therefore, was to specifically investigate the parturient behaviour of Djallonké ewes and West African dwarf does as affected by age and parity of the dam, and number of foetuses carried by the dam.

\section{Materials and methods}

Experimental sites and systems of management The site for the study on sheep was the Ghana National Livestock Breeding Station at PongTamale in the Northern Region of Ghana (latitude $9^{\circ} 69^{\prime} \mathrm{N}$ and longitude $0^{\circ} 83^{\prime} \mathrm{W}$ ), while that for the study on goats was the Ghana National Goat Breeding Station at Kintampo in the Brong Ahafo Region of Ghana (latitude $7^{\circ} 40^{\prime} \mathrm{N}$ and longitude $\left.1^{\circ} 05^{\prime} \mathrm{W}\right)$. Both stations are managed by the Animal Production Directorate of the Ministry of Food and Agriculture.

The management practices at both breeding stations were similar. Each of the farms had several paddocks ranging from 1.2 to 2.5 ha. The different flocks on each farm were rotated on these paddocks containing grass forages such as Cynodon nlemfuensis and Panicum maximum mixed with Stylosanthes hamata and Centrosema pubescens. Two weeks before mating, animals were flushed (i.e., given high energy/protein ration). Ewes or does near term were sent to the holding pen and kept under constant supervision. After parturition, neonates were allowed to stay with their dams for at least $4 \mathrm{~h}$ before they were weighed, sexed and ear-tagged. The period of noninterference was necessary to allow enough time 
for dams and their offspring to develop mutual recognition before human interference at tagging.

\section{Sheep}

The Djallonké breed of sheep was used for the study. A total of 52 ewes consisting of 34 multiparous and 18 primiparous ewes of ages ranging from 1 to 5 were involved. Thirty-five of the ewes bore single lambs while the remaining 17 bore twins.

\section{Goats}

The West African dwarf breed of goat was used for the study. Seventy does consisting of 52 single-bearing and 18 twin-bearing mothers of ages ranging from 1 to 4 were involved. Thirtythree of the does were primiparous while the remaining 37 were multiparous.

\section{Parturient behaviour of ewes and does}

During parturition, the ewes and does were observed continuously and the following parturient parameters recorded:

i. Duration of parturition. This was calculated as the time interval between the onset of straining and the complete expulsion of the foetus.

ii. Posture during birth. This refers to the position in which birth was completed by the dam.

iii. Presentation. This refers to how the neonate was presented during its birth. An anterior, longitudinal, dorso-sacral position, with the head resting on the extended forelegs was recorded as normal presentation. Any position other than this was referred to as abnormal (breech or retained forelimbs) presentation.

iv. Interventions during births. Whether assistance was rendered during the delivery of any animal.

\section{Other parameters recorded}

Age, parity and number of foetuses carried by the dam. The dams were classified into two age groups as follows: young ( $\leq 2$ years) and old ( $>2$ years). They were also classified into two parity groups, primiparous (one gestation and parturition) and multiparous (two parturitions or more). The dams were also classified into two based on the number of foetuses carried as single and twin-bearing dams. The age and parity of dams were determined from farm records whilst the number of foetuses carried was observed as number of foetuses delivered and recorded.

\section{Statistical analyses}

The chi-square procedure (Little \& Hills, 1977) and t-test (2-tailed) of Lawes Agricultural Trust (1996) statistical package were used to find out the effect of age of dam, parity of dam, and number of foetuses carried by the dam on the aforementioned parturient behavioural parameters. All were compared at 5 per cent level.

\section{Results}

\section{Parturient behaviour of Djallonké ewes}

Birth was completed in recumbent position by 38 $(73.1 \%)$ of the ewes studied, while the rest completed birth standing. Fifty-one (98.1\%) presented their foetuses in an anterior, longitudinal, dorso-sacral position with the head resting on the extended forelimbs, while the remaining one $(1.9 \%)$ presented her foetus in a breech position. No assistance was rendered during the delivery of all the ewes studied (Table $1)$.

The duration of labour for the Djallonké ewes studied ranged from 9 to $125 \mathrm{~min}$ and 10 to 125 min for single and twin-bearing ewes, respectively. The mean duration for single-bearing ewes was 34.74 min while that for twin-bearing ewes was $56.94 \mathrm{~min}$. The duration of labour for all births averaged $42 \mathrm{~min}$, while the time interval between the births of first and second-born twins ranged from 1 to $10 \mathrm{~min}$ and averaged $3.82 \mathrm{~min}$ (Table 2). Visible contractions were intermittent in the early stages of labour and graduated into almost continuous muscular tension before the expulsion of a lamb. Parity and age of the dam significantly 
TABLE 1

Posture, Presentation and Intervention During the Delivery of Djallonké Ewes and West African Dwarf Does

\begin{tabular}{lcccccc}
\hline & \multicolumn{3}{c}{ Species } & & Goat \\
\hline Parameter & Total number \\
of ewes & No. & Percent & Total number \\
of does & No. & Percent \\
\hline Recumbent position & 52 & 38 & 73.1 & 70 & 58 & 82.9 \\
Normal presentation & 52 & 51 & 98.1 & 70 & 66 & 94.3 \\
Intervention during delivery & 52 & 0 & 0 & 70 & 0 & 0 \\
\hline
\end{tabular}

TABLE 2

Duration (min) of Labour in Djallonké Ewes and West African Dwarf Does

\begin{tabular}{|c|c|c|c|c|c|c|}
\hline \multirow[b]{3}{*}{ Type of birth } & \multicolumn{6}{|c|}{ Species } \\
\hline & \multicolumn{3}{|c|}{ Sheep } & \multicolumn{3}{|c|}{ Goat } \\
\hline & $\begin{array}{c}\text { Number of } \\
\text { ewes }\end{array}$ & $\begin{array}{l}\text { Range } \\
(\text { min) }\end{array}$ & $\begin{array}{l}\text { Mean } \\
\text { (min) }\end{array}$ & $\begin{array}{c}\text { Number of } \\
\text { does }\end{array}$ & $\begin{array}{l}\text { Range } \\
\text { (min) }\end{array}$ & $\begin{array}{l}\text { Mean } \\
(\min )\end{array}$ \\
\hline Single & 35 & $9-125$ & $34.74 \pm 7.92$ & 52 & $2-123$ & $19.96 \pm 6.67$ \\
\hline Twins & 17 & $10-125$ & $56.94 \pm 19.80$ & 18 & $10-68$ & $22.33 \pm 6.63$ \\
\hline $\begin{array}{l}\text { Time interval between the } \\
\text { births of first and second- } \\
\text { born twins }\end{array}$ & 17 & $1-10$ & $3.82 \pm 1.40$ & 18 & $2-11$ & $5.67 \pm 1.46$ \\
\hline All births & 52 & $9-125$ & $42.00 \pm 8.51$ & 70 & $2-123$ & $20.57 \pm 5.13$ \\
\hline
\end{tabular}

influenced $(P<0.05)$ the duration of labour in Djallonké ewes. The duration of labour in primiparous ewes (54.72 min) was significantly longer than in multiparous ewes (35.26 $\mathrm{min})$. Similarly, young ewes were in labour longer (51.32 min) than old ewes (33.37 min). However, age and parity of the dam did not significantly affect $(P>$ $0.05)$ the position in which birth was completed and presentation of lambs at birth (Table 3 ).

The position in which birth was completed and presentation of lambs at birth were not significantly influenced $(P>0.05)$ by number of foetuses carried by the dam. However, twinbearing ewes were in labour for a significantly longer period $(56.94 \mathrm{~min})(P<0.05)$ than singlebearing ewes (34.74 min) (Table 3).
Parturient behaviour of West African dwarf does

The physical effort of expelling the foetus was done in recumbent position by $58(82.9 \%)$ of the West African dwarf does while the remaining 12 $(17.1 \%)$ did so standing. Sixty-six $(94.3 \%)$ does presented their foetuses in an anterior, longitudinal, dorso-sacral position with the head resting on the extended forelimbs, while the remaining $4(5.7 \%)$ presented theirs abnormally. Two of the four does presented their kids in breech position while the other two presented theirs with two forelegs retained. Although instances of prolonged parturitions and abnormal presentation of foetuses were few, no assistance was required in even a single delivery (Table 1). Labour for the West African dwarf does studied 
TABLE 3

Effect of Parity, Age and Number of Foetuses Carried on the Duration (min) of Labour, Posture and Presentation of Foetuses During the Delivery of Djallonké Ewes

\begin{tabular}{|c|c|c|c|c|}
\hline Groups of ewes & No. & $\begin{array}{l}\text { Duration of labour } \\
\text { (min) }\end{array}$ & $\begin{array}{c}\text { Number }(\%) \text { of ewes } \\
\text { that completed } \\
\text { birth in recumbent } \\
\text { position }\end{array}$ & $\begin{array}{c}\text { Number }(\%) \text { of ewes } \\
\text { that had their } \\
\text { foetuses normally } \\
\text { presented }\end{array}$ \\
\hline \multicolumn{5}{|l|}{ Parity } \\
\hline Primiparous & 18 & $54.72 \pm 18.05^{\mathrm{a}}$ & $13(72.2)$ & $17(94.4)$ \\
\hline Multiparous & 34 & $35.26 \pm 8.67^{b}$ & $25(73.5)$ & $34(100)$ \\
\hline \multicolumn{5}{|l|}{ Age } \\
\hline Young ( $\leq 2$ years $)$ & 25 & $51.32 \pm 13.54^{\mathrm{a}}$ & $17(68.0)$ & $24(96.0)$ \\
\hline Old (> 2 years) & 27 & $33.37 \pm 10.16^{\mathrm{b}}$ & $21(77.8)$ & $27(100)$ \\
\hline \multicolumn{5}{|l|}{ Type of birth } \\
\hline Singles & 35 & $34.74 \pm 7.93^{\mathrm{a}}$ & $26(74.3)$ & $34(97.1)$ \\
\hline Twins & 17 & $56.94 \pm 19.70^{\mathrm{b}}$ & $12(70.6)$ & $17(100)$ \\
\hline
\end{tabular}

Means with different superscripts within a group and column are significantly different $(P<0.05)$

lasted on the average for $20.57 \mathrm{~min}$, and the mean durations for single and twin-bearing does were 19.96 and $22.33 \mathrm{~min}$, respectively (Table 2).

Parity and age of the dam had no significant effect $(P>0.05)$ on the duration of labour and presentation of kids at birth. However, labour for primiparous does was slightly longer than that for multiparous does. The position in which birth was completed was significantly influenced $(P<$ $0.05)$ by parity and age of the dam. Most primiparous does $(93.9 \%)$ completed birth in recumbent position compared to multiparous does $(73.0 \%)$. Also, more young does $(94.7 \%)$ completed birth in recumbent position than old does $(68.8 \%)$ (Table 4$)$.

The number of foetuses carried by the dam did not have any significant effect $(P>0.05)$ on the duration of labour, position in which birth was completed, and presentation of kids at birth. Although labour was slightly longer in twinbearing (22.33 min) than in single-bearing (19.96 $\mathrm{min}$ ) does, the difference between the two groups of does was not statistically significant $(P>0.05)$ (Table 4).

\section{Discussion}

The findings of this study showed that on the average, labour lasted 42 min in Djallonké ewes, being longer than the 30 min reported by Fraser \& Broom (1990) for Merino ewes. In goats, a shorter duration of $20.57 \mathrm{~min}$ was recorded, also being longer than the 13.3 min reported by Allan, Holst \& Hinch (1991) for Australian feral goats. The interval between the births of first and second-born twins in ewes ranged from 1 to 10 min, while that in does ranged from 2 to $11 \mathrm{~min}$. These were shorter than the range of 2 to $42 \mathrm{~min}$ reported by Lickliter (1985) in goats, though he further reported that the time interval was usually less than $10 \mathrm{~min}$. It was observed in this study that most of the time in labour between the appearance of the forelegs and birth was spent forcing the foetal head and shoulders through the birth canal. During this time, ewes and does showed the most conspicuous contractions of the parturitional sequence. Sometimes contractions actually lifted the hind quarters of recumbent females about 15 to $21 \mathrm{~cm}$ off the ground. 
TABLE 4

Effect of Parity, Age and Number of Foetuses Carried on the Duration (min) of Labour, Posture and Presentation of Foetuses During the Delivery of West African Dwarf Does

\begin{tabular}{|c|c|c|c|c|}
\hline Groups of does & No. & $\begin{array}{l}\text { Duration of labour } \\
\text { (min) }\end{array}$ & $\begin{array}{c}\text { Number }(\%) \text { of does } \\
\text { that completed } \\
\text { birth in recumbent } \\
\text { position }\end{array}$ & $\begin{array}{c}\text { Number }(\%) \text { of does } \\
\text { that had their } \\
\text { foetuses normally } \\
\text { presented }\end{array}$ \\
\hline \multicolumn{5}{|l|}{ Parity } \\
\hline Primiparous & 33 & $21.94 \pm 10.10^{\mathrm{a}}$ & $31(93.9)$ & $32(97.1)$ \\
\hline Multiparous & 37 & $19.35 \pm 4.83^{\mathrm{a}}$ & $27(73.0)$ & $34(91.4)$ \\
\hline \multicolumn{5}{|l|}{ Age } \\
\hline Young ( $\leq 2$ years $)$ & 38 & $20.08 \pm 8.60^{\mathrm{a}}$ & $36(94.7)$ & $37(97.4)$ \\
\hline Old (> 2 years) & 32 & $21.16 \pm 5.27^{\mathrm{a}}$ & $22(68.8)$ & $29(90.6)$ \\
\hline \multicolumn{5}{|l|}{ Type of birth } \\
\hline Singles & 52 & $19.96 \pm 6.67^{a}$ & $44(84.6)$ & $49(94.2)$ \\
\hline Twins & 18 & $22.33 \pm 6.63^{a}$ & $14(77.8)$ & $17(94.4)$ \\
\hline
\end{tabular}

Means with different superscripts within a group and column are significantly different $(P<0.05)$

The results of this study indicated that over 70 per cent of the ewes and does completed birth in recumbent position. This is consistent with the observations of Alexander (1960) and Arnold (1985) in ewes and Lickliter (1985) in goats. They reported that most parturient ewes and does completed birth in recumbent position. Alexander (1960) further reported that ewes may stand up during the final stages of expulsion, particularly if this final stage is protracted. Completing birth in recumbent position, especially if the dam remains lying for a while after birth, allows significant transfer of blood from the placenta to the neonate (Rossdale \& Short, 1967). Over 90 per cent of the ewes and does presented their foetuses normally; that is, in an anterior, longitudinal, dorso-sacral position, with the head resting on the extended forelegs. Similar observations have been reported by Alexander, Bradley \& Stevens (1993) in sheep and Lickliter (1985) in goats. Although instances of prolonged parturitions and abnormal presentation of foetuses were few in ewes and does, no assistance was needed in even a single delivery.

Primiparous and younger ewes on the average had a longer labour than multiparous and older ewes. Alexander et al. (1993) also observed a significant effect of parity on the duration of labour in sheep. They observed that the duration of labour was inversely proportional to the number of previous parturitions. As observed by Lynch, Hinch \& Adams (1992), a likely reason for this was the small size of the birth canal of primiparous animals in relation to the size of the foetus, leading to prolonged labour. In contrast to sheep, age and parity of the dam had no significant influence on the duration of labour in does. This is similar to the earlier findings of Awotwi et al. (1999). They attributed their findings to the fact that newborn kids of West African dwarf does were of very small size, weighing on the average $1.13 \mathrm{~kg}$. Therefore, the feto-pelvic proportion in the primiparous does was not significantly different from that of multiparous does; hence, duration of labour was not longer in primiparous animals.

The number of foetuses carried by the dam did not affect the duration of labour in goats. In ewes, twin-bearing ewes on the average had a longer labour than single-bearing ewes. This 
contrasts with the findings of Hafez (1968) who observed that single-bearing ewes were in labour longer than twin-bearing ewes. He suggested that the mass of conceptus might play a part in initiating uterine contractions and subsequent parturition.

Age and parity of the dam did not affect the position in which birth was completed in ewes. In does, births were completed in recumbent position by most primiparous and young does compared to multiparous and older does. In this study, the number of foetuses carried did not significantly influence the position in which birth was completed in sheep and goats. The age, parity of dam, and number of foetuses carried did not also affect the mode of presenting foetuses at birth in both species. These contrast with the observations of Alexander et al. (1993) who reported that more normal presentations were observed in multiparous than in primiparous ewes. They also observed that 85.8 per cent of 5year-old ewes presented their foetuses normally as against all the 2-year-old ewes.

\section{Conclusion}

On the average, labour lasted for about 42 and 21 min in ewes and does, respectively. The time interval between the births of first and secondborn twins ranged from 1 to $10 \mathrm{~min}$ and 2 to 11 min in ewes and does, respectively. Births were completed in recumbent position by 73.1 per cent of ewes and 82.9 per cent of does. Most ewes and does presented their foetuses normally, while none required any kind of assistance during delivery.

Age, parity and number of foetuses carried had no influence on the presentation of foetus at birth in sheep and goats. Although the duration of labour was not influenced by age, parity and number of foetuses carried in goats, in sheep primiparous and young ewes were in labour for a significantly longer period than multiparous and old ewes. Also, twin-bearing ewes spent more time in labour than single-bearing ewes. Unlike in ewes, more primiparous and younger does completed birth in recumbent position than multiparous and older does. However, the number of foetuses carried did not influence the position in which birth was completed in both species.

\section{REFERENCES}

Alexander, G. (1960) Maternal behaviour in the Merino ewe. Proc. Aust. Soc. Anim. Prod. 3, 105114.

Alexander, G., Bradley, L. R. \& Stevens, D. (1993) Effect of age and parity on maternal behaviour in single-bearing Merino ewes. Aust. J. exp. Agric. 33, 721-728.

Allan, C. J., Holst, P. J. \& Hinch, G. N. (1991) Behaviour of parturient Australian bush goats. 1. Doe behaviour and kid vigour. Appl. Anim. Behav. Sci. 32, 55-64.

Arnold, G. W. (1985) Parturient behaviour. In Ethology of farm animals (Chapter 27) (ed. A. F. Fraser), pp. 335-346. Elsevier, Amsterdam.

Awotwi, E. K., Agbodza, S., Oppong-Anane, K. \& Fianu, F. K. (1999) Periparturient behaviour of the West African dwarf goat. Ghana Jnl agric. Sci. 32, 95-100.

FAO (1986) Small ruminant production in the developing countries (ed.V. M. Timon and T. P. Hanraham), pp. 1, 203-210.

Fraser, A. F. (1968) Reproductive behaviour in ungulates. Academic Press, London. pp. 120-130, 150-155, 202.

Fraser, A. F. \& Broom, D. M. (1990) Farm animal behaviour and welfare, 3rd edn. Bailliere Tindall, London. pp. 208-236.

Hafez, E. S. E. (1968) Gestation, prenatal development and parturition. Reproduction in farm animals (ed. E. S. E. Hafez), 2nd edn. Lea and Febiger, Philadelphia. 173 pp.

Lawes Agricultural Trust (1996) Gentstat 5 for personal computers, 2 nd edn.Version 3.2. IACRRothamsted.

Lickliter, R. E. (1985) Behaviour associated with parturition in the domestic goat. Appl. Anim. Behav. Sci. 13, 335-345.

Little, T. M. \& Hills, F. J. (1977) Agricultural experimentation. John Wiley and Sons, New York. pp. 270-282.

Lynch, J. J., Hinch, G. N. \& Adams, D. B. (1992) The behaviour of sheep. In Biological principles and implications for production, pp. 153-177. 
CSIRO, Australia.

Oppong, E. N. W. (1965) A note on goats in Ghana with reference to the need to develop husbandry to improve the nation's diet. Ghana Fmr 9, 144-149.

Robert, E. T. \& Ralph, B. (1988) Scientific Farm
Animal Production, 3rd edn. Macmillan Publishing Company, New York. pp. 1-26.

Rossdale, P. D. \& Short, R. V. (1967) The time of foaling of thoroughbred mares. J. Reprod. Fert. 13, 341-343. 